\title{
PEMBERIAN INSENTIF PENANAMAN MODAL SEBAGAI UPAYA DAYA TARIK INVESTASI DI DAERAH
}

\author{
Ahmad Zazili, Fathoni, Ade Arif Firmansyah \\ Fakultas Hukum Universitas Lampung \\ Jalan. Prof. Dr. Soemantri Brodjonegoro No. 1 Bandar Lampung \\ E-mail: zazy_01@yahoo.co.id
}

\begin{abstract}
Investment is important element in the implementation of the economy in regions, that is as efforts to improve economic growth, create jobs, upgrading the development sustainable economic. Not easily attract investor to invested in the required policies and strategies to attract investors. One policy that you can do is the policy of incentives investment (an investment). This study looked at policy to invite the investors to invest in the form of investment; incentives that may be given investors to invest in the region. The methodology used normative study done by means of studying regulations be related to investment and legal products associated with local governments. The results showed first, the government has the authority to making policy incentives investment in regional policy; material incentives invesatasi adjustable covering: tax deduction, tax relief, or exemption tax; reduction, lightening, or exemption retribution; fund stimulant; the capital assistance.
\end{abstract}

Keywords: Capital Investment, Regional Invesment, Regional Autonomy.

\begin{abstract}
ABSTRAK
Penanaman modal merupakan elemen penting dalam penyelenggaraan perekonomian di daerah, yaitu sebagai upaya meningkatkan pertumbuhan ekonomi, menciptakan lapangan kerja, meningkatkan pembangunan ekonomi yang berkelanjutan. Tidak mudah menarik investor untuk menanamkan modalnya di daerah diperlukan kebijakan dan strategi untuk menarik minat para investor. Salah satu kebijakan yang dapat dilakukan adalah kebijakan pemberian insentif Penanaman Modal (investasi). Penelitian ini mengkaji kebijakan untuk mengundang para investor agar berinvestasi di daerah; bentuk insentif investasi yang dapat diberikan kepada investor agar berinvestasi di daerah. Metode penelitian yang digunakan penelitian normatif dilakukan dengan cara mengkaji ketentuan-ketentuan yang berlaku yang berkenaan dengan penanaman modal dan produk hukum terkait dengan pemeritahan daerah. Hasil penelitian menunjukan pertama, bahwa pemerintah memiliki kewenangan untuk membuat kebijakan pemberian insentif penanaman modal di daerah; materi kebijakan pemberian insentif invesatasi yang dapat diatur meliputi: Pengurangan Pajak, keringanan pajak, atau pembebasan pajak daerah; Pengurangan, keringanan, atau pembebasan retribusi daerah; Pemberian dana stimulan; dan atau Pemberian bantuan modal.
\end{abstract}

Kata Kunci: Insentif Penanaman Modal, Investasi Daerah, Otonomi Daerah.

Pertumbuhan ekonomi merupakan salah satu indikator dalam kemajuan perekonomian daerah. Pemerintah daerah harus dapat memanfaatkan sumber daya potensial yang ada di daerah melalui kegiatan pengembangan, pengawasan, pengendalian dan promosi investasi guna menunjang per- 
tumbuhan ekonomi daerah. Kebijakan daya tarik investasi perlu dilakukan dengan tujuan mengundang investor untuk menanamkan modalnya. Investor dalam menanamkan modalnya sangat selektif dan berhati-hati sebab terkait dengan aspek financial. Aspek-aspek yang dipertimbangkan investor adalah daerah-daerah yang mempunyai daya tarik seperti infrastruktur yang memadai, iklim investasi yang kondusif, stabilitas keamanan dan politik, stabilitas ekonomi makro, penegakan hukum, ketersediaan tenaga kerja, kebijakan atau regulasi dari pemerintah setempat. Berkenaan dengan hal tersebut maka setiap daerah perlu menawarkan insentif investasi berupa fasilitas-fasilitas kemudahan investasi serta layanan yang cepat.

Berdasarkan pada uraian latar belakang di atas, maka dalam penelitian ini mengkaji kebijakan pemberian insentif penanaman modal di daerah, agar pembahasan terfokus dan terarah maka permasalahan adalah sebagai berikut: bagaimanakah Kebijakan yang dapat ditempuh untuk mengundang para investor agar berinvestasi di daerah?. Apakah bentuk insentif investasi dapat diberikan kepada investor agar berinvestasi di daerah?

\section{Metode Penelitian}

Penelitian ini merupakan penelitian hukum dengan pendekatan normatif, yaitu mengkaji ketentuan-ketentuan yang berlaku yang berkenaan dengan penanaman modal dan produk hukum terkait dengan pemeritahan daerah. Produk hokum dimaksud adalah Undang-Undang Nomor 33 Tahun 2004 tentang Perimbangan Keuangan antara Pemerintah Pusat dan Pemerintahan Daerah; Undang-Undang Nomor 25 Tahun 2007 tentang Penanaman Modal; Undang-Undang Nomor 23 Tahun 2014 Tentang Pemerintahan Daerah (Lembaran Negara Republik Indonesia Tahun 2014; Peraturan Pemerintah Nomor 45 Tahun 2008 tentang Pedoman Pemberian Insentif dan Pembe- rian Kemudahan Penanaman Modal di Daerah. Peraturan Menteri Dalam Negeri Nomor 64 Tahun 2012 tentang Pedoman Pelaksanaan Pemberian Insentif dan Pemberian Kemudahan Penanaman Modal.

Analisis secara normatif-kualitatif, yaitu memberi arti dan menginterpretasikan setiap bahan hukum yang telah diolah kemudian diuraikan secara komprehensif dan mendalam dalam bentuk uraian kalimat yang sistematis untuk kemudian ditarik kesimpulan.

\section{Kebijakan Pemberian Insentif Investasi di Daerah}

Istilah kebijakan atau kebijaksanaan yang diterjemahkan dari kata policy memang biasanya dikaitkan dengan keputusan pemerintah karena hanya pemerintah yang mempunyai wewenang atau kekuasaan untuk mengarahkan masyarakat dan bertanggungjawab melayani kepentingan umum. Pengertian kebijakan publik apabila diterjemahkan dalam bahasa hukum Indonesia maka kata kebijakan atau kebijaksanaan bermakna kewenangan penguasa untuk membuat suatu keputusan bagi kepentingan public (S. Zainal Abidin, 2006, 10).

Thomas R. Dye (Joko Widodo, 2007, 12) mengartikan kebijakan publik sebagai apapun yang pemerintah pilih untuk melakukan atau tidak melakukan sesuatu (whatever government choose to do or not to do). Menurut James E.Anderson (Joko Widodo, 2007, 20), public policies are those policies developed by governmental bodies and officials. Pengertian tersebut menjelaskan bahwa:

1) Kebijakan pemerintah selalu mempunyai tujuan tertentu atau merupakan tindakan yang berorientasi pada tujuan;

2) Kebijakan itu berisi tindakan-tindakan atau pola-pola tindakan para pejabat pemerintahan;

3) Kebijakan itu merupakan sesuatu yang benarbenar dilakukan pemerintah, bukan sesuatu 
yang baru yang menjadi maksud atau pernyataan pemerintah untuk melakukan sesuatu;

4) Kebijakan pemerintah bersifat positif, dalam arti merupakan keputusan pemerintah untuk melakukan sesuatu atau tidak melakukan sesuatu; dan

5) Kebijakan pemerintah yang berarti positif didasarkan atau selalu dilandaskan pada peraturan-peraturan atau perundang-undangan yang bersifat memaksa (otoritatif).

Ada beberapa Model Kebijakan yang oleh Nicholas Henry (Irfan Islamy, 2007, 37) dikelompokan menjadi 2 klasifikasi besar yakni:

1) Kebijaksanaan negara dianalisa dari sudut proses, bersifat deskriptif yaitu mencoba untuk menggambarkan bagaimana kebijaksanaan negara dibuat. Model yang termasuk dalam pengelompokan ini diantaranya institusional, elit massa, kelompok dan sistem;

2) Kebijaksanaan negara dianalisa dari sudut hasil dan akibatnya, bersifat preskriptif yaitu menunjukkan cara-cara untuk meningkatkan kualitas isi, hasil dan akibat dari kebijakan negara. Model yang termasuk dalam pengelompokkan ini adalah rational comprehensive dan incremental.

Kebijakan pemberian insentif investasi merupakan bagian dari kebijakan investasi. Kata investasi memiliki pengertian yang lebih luas karena dapat mencakup baik investasi langsung (direct investment) maupun investasi tidak langsung (portfolio investment), sedangkan kata penanaman modal lebih mempunyai konotasi kepada investasi langsung. Penanaman modal baik langsung atau tidak langsung memiliki unsur-unsur, adanya motif untuk meningkatkan atau setidak-tidaknya mempertahankan nilai modalnya (Ida Bagus Rahmdi Supancana, 2006, 1).

Investasi secara langsung selalu dikaitkan adanya keterlibatan secara langsung dari pemilik modal dalam kegiatan pengelolaan modal (Dhaniswara K. Harjono, 2007, 2). Dalam penanaman modal secara langsung, pihak investor langsung terlibat dalam kegiatan pengelolaan usaha dan bertanggung jawab secara langsung apabila terjadi suatu kerugian (N. Rosyidah Rakhmawati, 2003, 11. Dalam penanaman modal secara langsung, pihak investor langsung terlibat dalam kegiatan pengelolaan usaha dan bertanggung jawab secara langsung apabila terjadi suatu kerugian (Hulaman Panjaitan dan Anner Sianipar, 2008, 41).

Menurut ketentuan Pasal 1 Angka (1) UU No. 25 Tahun 2007 tentang Penanaman Modal, pengertian Penanaman Modal sebagai “Kegiatan menanam modal, baik oleh penanam modal dalam negeri maupun penanam modal asing untuk melakukan kegiatan usaha di wilayah Republik Indonesia. Penanaman modal menjadi bagian dari penyelenggaraan perekonomian nasional dan ditempatkan sebagai upaya untuk meningkatkan pertumbuhan ekonomi nasional, menciptakan lapangan kerja, mendorong pembangunan ekonomi kerakyatan (Rahayu Hartini, 2009, 48).

Penanaman modal (investasi) mempunyai peranan yang sangat penting untuk menggerakkan dan memacu pertumbuhan ekonomi suatu negara atau daerah. Hampir semua pakar ekonomi berpendapat bahwa penanaman modal adalah driving force setiap proses pembangunan ekonomi, karena kemampuannya dapat menggerakkan aspek-aspek pembangunan lainnya seperti sumber modal, sumber teknologi, memperluas kesempatan kerja dan lain- lain. Dalam konteks ini, makin cepat dihapuskannya aturan-aturan hukum penamanam modal yang counter-productive, berarti makin baik daya tariknya untuk memobilisasi sumber daya modal untuk tujuan penanaman modal (easy of entry dan easy of resources mobilization). Hal ini penting artinya untuk memperbaiki iklim penanaman modal, yang bermanfaat bukan hanya bagi perusahaan-perusahaan, tetapi juga memberikan manfaat sebesar-besarnya 
bagi masyarakat. Sebagai negara hukum yang demokratis, segala tindakan yang dilakukan baik oleh pemerintah sendiri maupun masyarakat harus senantiasa berpedoman dan berdasar pada hukum yang berlaku.

Menurut Organization for Economic Cooperation and Development (OECD), terminologi penanaman modal langsung tercermin pada keinginan kuat dari penanam modal untuk menanamkan modalnya yang berpengaruh kepada hubungan jangka panjang antara penanam modal dengan perusahaan tempat ia menanamkan modalnya dan pada derajat pengaruh yang signifikan pada manajemen perusahaan. Hal ini sejalan dengan pengertian penanaman modal langsung yang diberikan oleh Organization European Economic Cooperation (OEEC) yaitu: "acquisition of sufficient interest in an undertaking to insure its controle by the penanam modal".

Dalam merumuskan kebijakan pemberian insentif investasi harus memperhatikan asas-asas pembentukan peraturan perundang-undangan. Menurut Satjipto Rahardjo pembahasan mengenai asas hukum adalah membicarakan unsur yang penting dan pokok dari peraturan hukum, dan tidak berlebihan pula jika dikatakan bahwa asas hukum merupakan jantung dari peraturan hukum. Hal ini dikarenakan asas hukum adalah landasan yang paling luas bagi lahirnya suatu peraturan hukum. Ini berarti bahwa setiap peraturan hukum selalu bisa dikembalikan kepada asas-asas tersebut (Satjipto Rahardjo, 1986, 87). Asas hukum menjadikan hukum lebih dari sekedar peraturan yang dibuat dengan sengaja dan rasional, tetapi juga suatu dokumen moraletis.

Asas hukum memang tidak tampil sebagai aturan (rule) yang konkrit, tetapi lebih sebagai kaidah (norm) di belakang peraturan. Aturan itu rasional, sedangkan kaidah memiliki kandungan moral dan bersifat etis. Asas hukum menjelaskan dan memberi ratio legis mengapa harus ada aturan.
Ia menjadi penghubung antara peraturan hukum dan cita-cita sosial serta pandangan etis masyarakatnya (Satjipto Rahardjo, 2006, 124).

Kebijakan yang dituangkan dalam peraturan daerah sebagai salah satu bentuk peraturan perundang-undangan dalam pembentukannya tidak luput dari asas formal dan material. Untuk mendapatkan kualitas peraturan daerah yang seperti itu, maka dalam pembentukannya harus didasarkan pada beberapa asas. Menurut Van der Vlies sebagaimana dikutip oleh A. Hamid S. Attamimi, membedakan dua kategori asas-asas pembentukan peraturan perundang-undangan yang patut (algemene beginselen van behoorlijk regelgeving), yaitu asas formal dan asas material (A. Hamid S. Attamimi, 1990, 35).

Asas-asas formal meliputi: Asas tujuan jelas; Asas lembaga yang tepat; Asas perlunya pengaturan; Asas dapat dilaksanakan; dan Asas Konsensus. Asas-asas material meliputi: Asas kejelasan terminologi dan sistematika; Asas bahwa peraturan perundang-undangan mudah dikenali; Asas persamaan; Asas kepastian hukum; dan Asas pelaksanaan hukum sesuai dengan keadaan individual. Asas-asas pembentukan peraturan perundang-undangan penting untuk diterapkan karena dalam era otonomi luas dapat terjadi pembentuk peraturan daerah membuat suatu peraturan hanya atas dasar intuisi sesaat bukan karena kebutuhan masyarakat.

Berdasarkan Pasal 5 Undang-Undang Nomor 11 Tahun 2012, dinyatakan: Dalam membentuk Peraturan Perundang-undangan harus dilakukan berdasarkan pada asas Pembentukan Peraturan Perundang-undangan yang baik, yang meliputi: kejelasan tujuan; kelembagaan atau pejabat pembentuk yang tepat; kesesuaian antara jenis, hierarki, dan materi muatan; dapat dilaksanakan; kedayagunaan dan kehasilgunaan; kejelasan rumusan; dan keterbukaan. Dalam penjelasan Pasal 5 di atas, dijelaskan: 
1) Yang dimaksud asas kejelasan tujuan adalah bahwa setiap Pembentukan Peraturan Perundang-undangan harus mempunyai tujuan yang jelas yang hendak dicapai.

2) Yang dimaksud "asas kelembagaan atau pejabat pembentuk yang tepat" adalah bahwa setiap jenis Peraturan Perundang-undangan harus dibuat oleh lembaga negara atau pejabat Pembentuk Peraturan Perundang-undangan yang berwenang. Peraturan Perundang-undangan tersebut dapat dibatalkan atau batal demi hukum apabila dibuat oleh lembaga negara atau pejabat yang tidak berwenang.

3) Yang dimaksud dengan "asas kesesuaian antara jenis, hierarki, dan materi muatan" adalah bahwa dalam Pembentukan Peraturan Perundang-undangan harus benar-benar memperhatikan materi muatan yang tepat sesuai dengan jenis dan hierarki Peraturan Perundangundangan.

4) Yang dimaksud dengan "asas dapat dilaksanakan" adalah bahwa setiap Pembentukan Peraturan Perundang-undangan harus memperhitungkan efektivitas Peraturan Perundangundangan tersebut di dalam masyarakat, baik secara filosofis, sosiologis, maupun yuridis.

5) Yang dimaksud dengan "asas kedayagunaan dan kehasilgunaan" adalah bahwa setiap Peraturan Perundang-undangan dibuat karena memang benar-benar dibutuhkan dan bermanfaat dalam mengatur kehidupan bermasyarakat, berbangsa, dan bernegara.

6) Yang dimaksud dengan "asas kejelasan rumusan" adalah bahwa setiap Peraturan Perundangundangan harus memenuhi persyaratan teknis penyusunan Peraturan Perundang-undangan, sistematika, pilihan kata atau istilah, serta bahasa hukum yang jelas dan mudah dimengerti sehingga tidak menimbulkan berbagai macam interpretasi dalam pelaksanaannya.

7) Yang dimaksud dengan "asas keterbukaan" adalah bahwa dalam Pembentukan Peraturan
Perundang-undangan mulai dari perencanaan, penyusunan, pembahasan, pengesahan atau penetapan, dan pengundangan bersifat transparan dan terbuka. Dengan demikian, seluruh lapisan masyarakat mempunyai kesempatan yang seluas-luasnya untuk memberikan masukan dalam Pembentukan Peraturan Perundang-undangan.

Asas-asas pembentukan peraturan perundangundangan tersebut di atas menjadi landasan dalam penyusunan kebijakan pemberian insentif di daerah. Dalam menentukan materi muatan kebijakan pemberian insentif investasi, sebagaimana dinyatakan pada Pasal 6. Dinyatakan bahwa: Materi muatan Peraturan Perundang-undangan harus mencerminkan asas berikut:

1. Asas pengayoman adalah bahwa setiap materi muatan peraturan perundang-undangan harus berfungsi memberikan pelindungan untuk menciptakan ketentraman masyarakat;

2. Asas kemanusiaan adalah bahwa setiap materi muatan peraturan perundang-undangan harus mencerminkan pelindungan dan penghormatan hak asasi manusia serta harkat dan martabat setiap warga negara dan penduduk Indonesia secara proporsional;

3. Asas kebangsaan adalah bahwa setiap materi muatan peraturan perundang-undangan harus mencerminkan sifat dan watak bangsa Indonesia yang majemuk dengan tetap menjaga prinsip Negara Kesatuan Republik Indonesia;

4. Asas kekeluargaan adalah bahwa setiap materi muatan peraturan perundang-undangan harus mencerminkan musyawarah untuk mencapai mufakat dalam setiap pengambilan keputusan;

5. Asas kenusantaraan adalah bahwa setiap materi muatan peraturan perundang-undangan senantiasa memperhatikan kepentingan seluruh wilayah Indonesia dan materi muatan peraturan perundang-undangan yang dibuat di daerah merupakan bagian dari sistem 
hukum nasional yang berdasarkan Pancasila dan Undang-Undang Dasar Negara Republik Indonesia Tahun 1945;

6. Asas Bhinneka Tunggal Ika adalah bahwa materi muatan peraturan perundang-undangan harus memperhatikan keragaman penduduk, agama, suku dan golongan, kondisi khusus daerah serta budaya dalam kehidupan bermasyarakat, berbangsa, dan bernegara;

7. Asas keadilan adalah bahwa setiap materi muatan peraturan perundang-undangan harus mencerminkan keadilan secara proporsional bagi setiap warga negara;

8. Asas kesamaan kedudukan dalam hukum dan pemerintahan adalah bahwa setiap materi muatan peraturan perundang-undangan tidak boleh memuat hal yang bersifat membedakan berdasarkan latar belakang, antara lain, agama, suku, ras, golongan, gender, atau status sosial;

9. Asas ketertiban dan kepastian hukum adalah bahwa setiap materi muatan peraturan perundang-undangan harus dapat mewujudkan ketertiban dalam masyarakat melalui jaminan kepastian hukum;

10. Asas keseimbangan, keserasian, dan keselarasan adalah bahwa setiap materi muatan peraturan perundang-undangan harus mencerminkan keseimbangan, keserasian, dan keselarasan, antara kepentingan individu, masyarakat dan kepentingan bangsa dan Negara; dan

11. Asas lain sesuai dengan bidang hukum Peraturan Perundang-undangan yang bersangkutan. Asas dimaksud antara lain, dalam Hukum Pidana, misalnya, asas legalitas, asas tiada hukuman tanpa kesalahan, asas pembinaan narapidana, dan asas praduga tak bersalah. Dalam Hukum Perdata, misalnya, dalam hukum perjanjian, antara lain, asas kesepakatan, kebebasan berkontrak, dan itikad baik.
Materi muatan kebijakan pemberian insentif penanaman modal di daerah yang perlu diatur dalam peraturan daerah setidaknya meliputi aspekaspek di bawah ini:

a) Prinsip dan Tujuan Pemberian Insentif Penanaman Modal, sumber acuan adalah Pasal 2 Peraturan Pemerintah Nomor 45 Tahun 2008 tentang Pedoman Pemberian Insentif dan Pemberian Kemudahan Penanaman Modal di Daerah yang menentukan Pemberian insentif dan pemberian kemudahan dilakukan berdasarkan prinsip: kepastian hukum; kesetaraan; transparansi; akuntabilitas; dan efektif dan efisien. Selanjutnya pada Pasal 1 Peraturan Pemerintah Nomor 45 Tahun 2008 tentang Pedoman Pemberian Insentif dan Pemberian Kemudahan Penanaman Modal di Daerah, yang menegaskan pemberian insentif adalah dukungan dari pemerintah daerah kepada penanam modal dalam rangka peningkatan penanaman modal di daerah. Sumber acuan lainnya adalah Pasal 1 Permendagri No 64 Tahun 2012 Tujuan Pemberian Insentif adalah Mendukung Peningkatan Penanaman Modal;

b) Jenis Usaha; dalam menentukan jenis badan usaha yang dapat memperoleh insentif investasi dapat merujuk pada Pasal 36 Permendagri Nomor 64 Tahun 2012, Jenis atau bidang usaha yang dapat memperoleh insentif dan kemudahan antara lain: usaha mikro, kecil, menengah, dan koperasi; usaha yang dipersyaratkan dengan kemitraan; usaha yang dipersyaratkan kepemilikan modalnya; usaha yang dipersyaratkan dengan lokasi tertentu; dan usaha yang dipersyaratkan dengan perizinan khusus.

c) Bentuk dan Kriteria. Dalam menentukan Bentuk dan Kreteria insentif investasi dapat merujuk ketentuan Pasal 3 Peraturan Pemerintah Nomor 45 Tahun 2008 tentang Pedoman Pemberian Insentif dan Pemberian Kemudahan Penanaman Modal di Daerah. 
Adapun bentuk Insentif sebagaimana dimaksud berupa pengurangan, keringanan, atau pembebasan pajak daerah, Pengurangan, keringanan, atau pembebasan restrubusi daerah; Pemberian dana stimulant; dan atau Pemberian bantuan modal. Pada Pasal 9 Permendagri No 64 Tahun 2012 tentang Pedoman Pelaksanaan Pemberian Insentif dan Pemberian Kemudahan Penanaman Modal Pemberian insentif dapat berbentuk: Penguranga, keringanan, atau pembebasan pajak daerah; Pengurangan, keringanan, atau pembebasan restrubusi daerah; Pemberian dana stimulan; dan atau Pemberian bantuan modal. Pasal 19 Permendagri No 64 Tahun 2012 tentang Pedoman Pelaksanaan Pemberian Insentif dan Pemberian Kemudahan Penanaman Modal Pemberian insentif dan pemberian kemudahan diberikan kepada penanam modal yang sekurang-kurangnya memenuhi salah satu kriteria sebagai berikut:

a. Memberikan kontribusi bagi peningkatan pendapatan masyarakat;

b. Menyerap banyak tenaga kerja lokal;

c. Menggunakan sebagian besar sumberdaya lokal;

d. Memberikan kontribusi bagi peningkatan pelayanan publik;

e. Memberikan kontribusi dalam peningkatan Produk Domestik Regional Bruto;

f. Berwawasan lingkungan dan berkelanjutan;

g. Termasuk skala prioritas tinggi;

h. Termasuk pembangunan infrastruktur;

i. Melakukan alih teknologi;

j. Melakukan industri pionir;

k. Berada di daerah terpencil, daerah tertinggal, atau daerah perbatasan;

1. Melaksanakan kegiatan penelitian, pengembangan, dan inovasi;

m. Bermitra dengan usaha mikro, kecil, menengah, atau koperasi; atau industri yang menggunakan barang modal, mesin, atau peralatan yang diproduksi di dalam negeri.

d) Tata cara permohonan dan kriteria. Dalam merumuskan kebijakan Tata cara permohonan dan kriteria penerima insentif investasi dapat merujuk ketentuan Pasal 5. Dinyatakan bahwa pemberian insentif dan pemberian kemudahan penanaman modal dilakukan dengan tata cara sebagai berikut: Penanam modal yang ingin mendapatkan insentif dan kemudahan harus mengajukan usulan kepada Pemerintah Daerah yang memuat Usulan sebagaimana dimaksud pada huruf a, memuat: lingkup usaha; kinerja manajemen; dan perkembangan usaha. Khusus untuk usaha mikro, usaha kecil, usaha menengah dan koperasi usulan cukup dengan menyampaikan kebutuhan insentif dan kemudahan.

e) Hak dan Kewajiban penerima insentif penanaman modal. Dalam merumuskan ketentuan tentang hak dan kewajiban penerima insentif penanaman modal dapat mengacu pada Pasal 14 Undang-Undang Nomor 25 Tahun 2007 Tentang Penanaman Modal, Setiap penanam modal berhak mendapat:

a. Kepastian hak, hukum, dan perlindungan;

b. Informasi yang terbuka mengenai bidang usaha yang dijalankannya;

c. Hak pelayanan; dan

d. Berbagai bentuk fasilitas kemudahan sesuai dengan ketentuan peraturan perundang-undangan.

Sedangkan dalam merumuskan kewajiban penerima insentif penenaman modal dapat merujuk pada Pasal 15 Undang-Undang Nomor 25 Tahun 2007 Tentang Penanaman Modal, Setiap penanam modal berkewajiban: a.menerapkan prinsip tata kelola perusahaan yang baik; b. melaksanakan tanggung jawab sosial perusahaan; c. membuat laporan tentang kegiatan penanaman modal dan menyampaikannya kepada Badan Koordinasi Penanaman 
Modal; d. menghormati tradisi budaya masyarakat sekitar lokasi kegiatan usaha penanaman modal; dan e. mematuhi semua ketentuan peraturan perundang-undangan.

Pasal 16 Undang-Undang Nomor 25 Tahun 2007 Tentang Penanaman Modal, Setiap penanam modal bertanggung jawab untuk:

a. Menjamin tersedianya modal yang berasal dari sumber yang tidak bertentangan dengan ketentuan peraturan perundangundangan;

b. Menanggung dan menyelesaikan segala kewajiban dan kerugian jika penanam modal menghentikan atau meninggalkan atau menelantarkan kegiatan usahanya secara sepihak sesuai dengan ketentuan peraturan perundang-undangan;

c. Menciptakan iklim usaha persaingan yang sehat, mencegah praktik monopoli, dan hal lain yang merugikan negara;

d. Menjaga kelestarian lingkungan hidup;

e. Menciptakan keselamatan, kesehatan, kenyamanan, dan kesejahteraan pekerja; dan

f. Mematuhi semua ketentuan peraturan perundang-undangan.

Pasal 17 Undang-Undang Nomor 25 Tahun 2007 Tentang Penanaman Modal, Penanam modal yang mengusahakan sumber daya alam yang tidak terbarukan wajib mengalokasikan dana secara bertahap untuk pemulihan lokasi yang memenuhi standar kelayakan lingkungan hidup, yang pelaksanaannya diatur sesuai dengan ketentuan peraturan perundang-undangan.

f) Pelaporan dan Evaluasi, dalam merumuskan norma Pelaporan dan Evaluasi dalam kebijakan insentif investasi dapat merujuk pada Pasal 11 Peraturan Pemerintah Nomor 45 Tahun 2008 Pedoman Pemberian Insentif dan Pemberian Kemudahan Penanaman Modal di Daerah, Penerima insentif dan penerima kemudahan penanaman modal menyampaikan laporan kepada kepala daerah paling sedikit 1 (satu) tahun sekali.

Laporan sebagaimana dimaksud pada ayat (1) paling sedikit memuat laporan penggunaan insentif dan/atau kemudahan, pengelolaan usaha, dan rencana kegiatan usaha. Selanjutnya pada Pasal 13 Peraturan Pemerintah Nomor 45 Tahun 2008 Pedoman Pemberian Insentif dan Pemberian Kemudahan Penanaman Modal di Daerah, Kepala daerah melakukan evaluasi terhadap kegiatan penanaman modal yang memperoleh insentif dan/atau kemudahan. Evaluasi terhadap kegiatan penanaman modal yang memperoleh insentif dan/atau kemudahan dilakukan 1 (satu) tahun sekali.

\section{Bentuk Pemberian Insentif Penanaman Modal/Investasi di Daerah}

Kompendium Bidang Investasi, Badan Pembinaan Hukum Nasional Kementerian Hukum Dan Hak Asasi Manusia RI, (BPHN RI, 2011, 60-61) mengemukakan bentuk pemberian insentif yang ada adalah sebagai berikut:

a. Insentif di bidang perpajakan

Peraturan Pemerintah Nomor 62 tahun 2008 tentang perubahan atas peraturan Pemerintah nomor 1 tahun 2007 tentang fasilitas pajak penghasilan untuk penanaman modal di bidang-bidang usaha tertentu dan/atau di daerah-daerah. Dengan terbitnya PP tersebut, jumlah bidang usaha dan daerah lokasi penanaman modal yang dapat memperoleh fasilitas pajak penghasilan bertambah. Dari semula, 15 bidang usaha dan 9 bidang usaha di daerah tertentu pada PP No. 1 tahun 2007 menjadi 23 bidang usaha dan 15 bidang usaha di daerah tertentu.

Fasilitas Pajak Penghasilan yang diberikan adalah dalam bentuk pengurangan penghasilan neto sebesar 30 persen dari jumlah Penanaman Modal, dibebankan selama 6 tahun 
masing-masing sebesar 5 persen per tahun. Kemudian, penyusutan dan amortisasi yang dipercepat, Pengenaan Pajak Penghasilan atas dividen yang dibayarkan kepada Subjek Pajak Luar Negeri sebesar 10 \% (persen), Kompensasi kerugian yang lebih lama dari 5 tahun tetapi tidak lebih dari 10 tahun. Peraturan ini akan dievaluasi dalam waktu paling lama dua tahun. Peraturan itu juga menetapkan bahwa wajib pajak yang melakukan kegiatan usaha di bidang usaha industri semen yang melakukan rekonstruksi akibat bencana tsunami dapat memperoleh fasilitas sejak tanggal 1 Januari 2005 untuk memperbaiki iklim penanaman modal dan meningkatkan daya saing nasional.

b. Insentif non pajak

Selain insentif dalam bidang pajak, insentif lain yang dapat diberikan oleh pemerintah yaitu dalam bentuk insentif non pajak seperti perizinan, kepastian hukum, keamanan, stabilitas moneter, inflasi yang stabil, adanya sumber daya alam yang memadai, pelayanan perbankan dan keuangan yang kondusif. Faktorfaktor ini sebenarnya yang lebih menjadi perangsang. Selain itu juga masalah pertanahan, hak guna usaha atau hak pakai, hak usaha, keluar masuk devisa yang tidak terlalu ketat, perizinan tenaga kerja asing, pembebasan bea masuk barang modal, dan faktor-faktor non pajak lainnya. Faktor-faktor non pajak seperti yang disebutkan di atas merupakan jenis insentif yang juga dapat menarik penanam modal untuk menanamkan modalnya. Terlebih lagi apabila insentif yang diberikan yaitu berupa paket insentif sehingga manfaat yang dirasakan oleh penanam modal akan semakin bertambah.

Jika dirumuskan dalam bentuk norma maka bentuk-bentuk pemberian insentif investasi yang dapat diberikan bagi para investor sebagai berikut: pemerintah daerah dapat memberikan insentif dan kemudahan kepada penanam modal yang meliputi: a. penanam modal baru dan akan membuka usaha; dan

b. penanam modal lama yang sudah melakukan usaha dan yang akan melakukan perluasan usaha.

Sedangkan penentuan jenis usaha dapat memperoleh insentif dan atau kemudahan penanaman modal meliputi: Penanaman Modal Asing dengan bidang usaha terbuka dengan persyaratan; dan Penanaman Modal Dalam Negeri dengan skala kecil, menengah dan besar yang meliputi:

a. Sektor pariwisata dan kebudayaan, termasuk sektor pendukungnya;

b. Sektor pendidikan, diprioritaskan pada usaha yang mendukung pengembangan fasilitas pendidikan;

c. Sektor pertanian, diprioritaskan pada pengolahan hasil pertanian;

d. Sektor perkebunan, diprioritas pada pengolahan hasil perkebunan;

e. Sektor peternakan, diprioritaskan pada usaha budi daya dan pengolahan hasil peternakan yang melakukan kemitraan dengan usaha mikro dan kecil;

f. Sektor perikanan dan kelautan, diprioritaskan pada usaha budi daya dan pengolahan hasil perikanan dan kelautan yang melakukan kemitraan dengan usaha mikro dan kecil;

g. Sektor perdagangan dan jasa, diprioritaskan pada usaha yang mendukung ekspor;

h. Sektor energi, diprioritaskan untuk energi terbarukan;

i. Sektor industri kreatif; dan

j. Jenis usaha yang bersedia menyesuaikan lokasi sesuai rencana tata ruang dapat diberikan insentif.

Ketentuan tentang bentuk dan kriteria insentif investasi dapat dirumuskan sebagai berikut: Pemberian insentif dapat berbentuk: pengurangan pajak daerah; dan pengurangan atau pem- 
bebasan retribusi daerah. Pemberian kemudahan dapat berbentuk: penyediaan informasi lahan atau lokasi; pemberian advokasi; dan percepatan pemberian perizinan. Kriteria pemberian insentif dan/atau pemberian kemudahan diberikan kepada penanam modal yang sekurang-kurangnya memenuhi salah satu kriteria sebagai berikut:

a. Menanamkan investasi lebih dari Rp. 500.000.000,- (lima ratus juta rupiah);

b. Menyerap banyak tenaga kerja lokal;

c. Melakukan industri pionir;

d. Berlokasi sesuai peruntukannya;

e. Bermitra dengan usaha mikro dan kecil; dan

f. Melakukan alih teknologi dan ramah lingkungan.

\section{Penutup}

Berdasarkan uraian yang telah dibahas di atas maka dapat disimpulkan, sebagai berikut: Pertama, salah satu upaya yang dapat dilakukan untuk mengelolah dan memanfaatkan potensi ekonomi tersebut adalah dengan menarik para investor, agar investor tertarik untuk menanamkan modalnya di daerah diperlukan kebijakan-kebijakan untuk memberikan daya tarik bagi investor melalui pemberian insentif dan kemudahan bagi penanaman modal.

Kedua, dasar hukum pembentukan perda insentif dan kemudahan penanaman modal di daerah adalah Undang-Undang Nomor 25 Tahun 2007; Undang-Undang Nomor 23 Tahun 2014; Peraturan Pemerintah Nomor 45 Tahun 2008; dan Permendagri Nomor 64 Tahun 2012 yang secara khusus memberikan kewenangan kepada Pemerintah Kabupaten Untuk membentuk perda Pemberian Insentif dan Kemudahan Penanaman Modal di daerah.

Sehubungan dengan hal di atas, seyogyanya setiap daerah disarankan untuk segera membentuk peraturan daerah tentang Pemberian Insentif dan kemudahan Bagi Penanaman Modal dengan tujuan untuk menarik minat investor menanamkan modalnya di daerah.

\section{DAFTAR PUSTAKA}

\section{Buku}

Attamini, A. Hamid S, 1990, Peranan Keputusan Presiden Republik Indonesia Dalam Penyelenggaraan Pemerintahan Negara, Fakultas Pascasarjana Universitas Indonesia, Surabaya.

Harjono, Dhaniswara K, 2007, Hukum Penanaman Modal: Tinjauan terhadap Pemberlakuan UU No. 25 Tahun 2007 Tentang Penanaman Modal, PT. Raharja Grafindo Persada, Jakarta.

Islamy, Irfan, 2007, Prinsip-Prinsip Perumusan Kebijaksanaan Negara, Bumi Aksara, Jakarta.

Panjaitan, Hulaman dan Anner Sianipar, 2008, Hukum Penanaman Modal Asing, CV. Indhill Co, Jakarta.

Rakhmawati, N. Rosyidah, 2003, Hukum Penanaman Modal di Indonesia Dalam Menghadapi Era Global, Bayumedia Publishing, Malang.

Rahardjo, Satjipto. 1986, Ilmu Hukum, Alumni, Bandung.

- - - - - - - - , 2006, Hukum dalam Jagat Ketertiban, UKI Press, Jakarta.

Supancana, Ida Bagus Rahmdi, 2006, Kerangka Hukum dan Kebijakan Investasi Langsung di Indonesia, PT. Ghalia Indonesia, Jakarta.

Widodo, Joko, 2007, Analisis Kebijakan Publik, Bayumedia, Malang.

\section{Artikel}

Badan Pembinaan Hukum Nasional Kementerian Hukum Dan Hak Asasi Manusia Ri, 2011, Kompendium bidang Hukum Investas, Jakarta.

Rahartini, Rahayu, 2009, Jurnal HUMANITY, Volume IV, Nomor 1, September, Universitas Muhammadiyah Malang, Malang.

\section{Peraturan Perundang-Undangan}

Undang-Undang Nomor 25 tahun 2007 tentang Penanaman Modal 


\section{Jurnal Cakrawala Hukum}

Vol.7, No.1 Juli 2016: 112-122

Undang-Undang Nomor 12 Tahun 2011 tentang Pembentukan Peraturan Perundang Undangan

Undang-Undang Nomor 23 tahun 2014 tentang pemerintahan daerah

Peraturan Pemerintah Nomor 45 Tahun 2008 tentang Pedoman Pemberian Insentif dan Pemberian Kemudahan Penanaman Modal di Daerah
Peraturan Pemerintah Nomor 62 Tahun 2008 Tentang Perubahan Atas Peraturan Pemerintah Nomor 1 Tahun 2007 Tentang Fasilitas Pajak Penghasilan Untuk Penanaman Modal Di Bidang-Bidang Usaha Tertentu Daniatau Di Daerah-Daerah

Permendagri Nomor 64 Tahun 2012 Tentang Pedoman Pelaksanaan Pemberian Insentif dan Pemberian Kemudahan Penanaman Modal 